\title{
Bioprospecting of Bacillus thuringiensis in the control of Aedes aegypti larvae
}

\section{Aline Souza Soares*, Lara Teixeira Melo Costa, Cristina Almeida da Silva, Suetônio Fernandes dos Santos and Raimundo Wagner de Souza Aguiar}

Universidade Federal do Tocantins Departamento de Biotecnologia. Campus Universitário de Gurupi. Tocantins-T0, Brazil. Email: bioalinesouza@gmail.com.

\begin{abstract}
Aedes aegypti (Diptera: Culicidae) is the main vector of Dengue, Zika and Chikungunya, diseases that have attracted the attention of scientific society and the population in general, due to epidemiological outbreaks and numerous health hazards and the imminent risk of death. Much has been discussed about more efficient forms of control for this mosquito, considering that the chemical control, currently used, has been causing impacts on the environment and the health of the population. Thus, alternative methods have been evaluated. Among them, biological control through products formulated from Bacillus thuringiensis has stood out, as biotechnological advances have allowed to improve and enhance the products already on the market, as well as to develop new bioinsecticides from the entomopathogenic proteins produced by these microorganisms, aiming to make the larvae control more and more effective. To this end, this study aimed to carry out a bibliographic survey on the use of Bacillus thuringiensis as a form of biological control of Aedes aegypti larvae, due to the need to use safer and more effective methods of control for disease vector insects.
\end{abstract}

Keywords: Biological control; Dengue; Chikungunya; Zika; Cristals; Culicid.
Received

August 4, 2020

Accepted

August 28, 2020

Released

August 31, 2020

Full Text Article

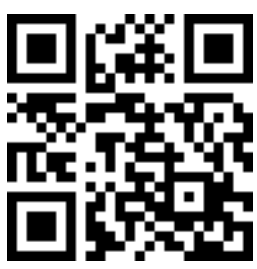




\section{Introduction}

The genus Aedes has several species distributed throughout the world. Among them, Aedes aegypti (Diptera: Culicidae) stands out, mosquitoes abundant throughout Brazil and distributed in approximately 4,523 municipalities (Zara et al., 2016). They are important vectors of arboviruses that cause diseases such as dengue, chikungunya, zika and yellow fever (Miller and Ballinger, 1988; Lourenço-de-Oliveira et al., 2004).

The ease with which populations of this culicid increase and remain in urban centers is worrying, because, when they reproduce, they use several places that contain standing water to lay eggs, which, because they are resistant to desiccation, can remain viable in dry places for more than a year (Consoli and Lourenço-de-Oliveira, 1994).

Due to the rapid proliferation of mosquitoes, the number of people infected by the arboviruses transmitted by them has increased significantly. This has a great impact on public health, requiring the development of preventive measures, as well as the effective control of these vectors.

The use of chemical insecticides is the most used method to control these mosquitoes, however, problems related to the environment and the health of the population have led researchers to seek alternative ways to eradicate them. In this sense, biological control through the use of entomopathogenic bacteria or formulated from them, can be an important ally in the fight against $A$. aegypti larvae.

The Bacillus genus is a large group that comprises several species of bacteria, such as B. alvei, B. circulans, B. macerans, $B$. cereus, B. amyloliquefaciens, B. subtilis, $B$. pumilis, $B$. licheniformis, B. megaterium, B. flexus, B. fimus, B. neurolyticus, B. brevis, B. sphaericus, $B$. lentus, B. coagulans, B. stearothermophilus and B. thuringiensis (Barros, 2004). Among them, B. thuringiensis (Bt) has a high degree of toxicity for larvae of different insect species, and can also be used together with chemicals to increase control efficiency (Chui et al., 1995; Polanczyk et al., 2003), without causing a reduction in the biodiversity of the treated sites (Becker, 2000).

Therefore, this work aimed to carry out a bibliographic survey on the efficiency of $B$. thuringiensis (Bt) in the control of $A$. aegypti larvae, a vector of several arboviruses that have an impact on health and society. Scientific data is necessary for the development of new technologies to be used to benefit the environment and the world population.

\section{Aedes aegypti}

Aedes aegypti Linnaeus, 1762 (Diptera: Culicidae) is originally from Africa. However, as a result of the destruction of natural habitats, they would have gone through a process of genetic selection, and selected varieties found, in altered areas and in human clusters, environments suitable for their survival (Viveiros, 2010). From Africa, they migrated to Southern Europe and Asia by sea transport (Lounibos, 2002) and spread throughout the world.

Part of the life cycle occurs in water and, therefore, they have great adaptive capacity to the type and quality of the reservoirs where they develop. Thus, although they can develop in polluted waters, containing different concentrations of organic matter, including domestic sewage (Beserra et al., 2009), they prefer cleaner waters found in household and household containers including unused tires, cans, bottles, dishes with vase, open water tanks, unused pools, among others (Neves, 2005).

Currently, it is considered cosmopolitan. It has a wide distribution, being found both in urban and suburban areas of tropical and subtropical regions, between latitudes $35^{\circ} \mathrm{N}$ and $35^{\circ} \mathrm{S}$, as well as, latitude up to $45^{\circ} \mathrm{N}$ (Viveiros, 2010). They present complete metamorphosis and the life cycle comprises four phases: egg, larva (4 instars), pupa and the adult (Figure 1) (Gadelha and Toda, 1985; Araújo, 2011). 


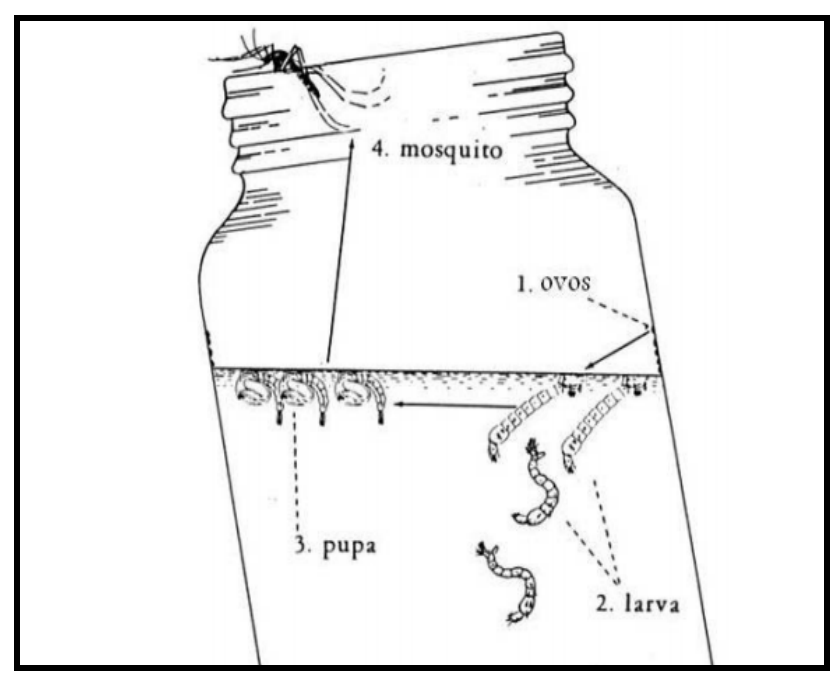

Figure 1. Life cycle of culicids. 1 - egg, 2 - larva (4 instars), 3 - pupa, 4 - adult mosquito. Source: Adapted from Araújo (2011).

Upon contact with water, the larvae hatch from the eggs, passing through four instars (L1, L2, L3 and L4). The duration of each instar varies according to the temperature, availability of food and larval density at the breeding site (Araújo, 2011).

These larvae feed mainly on aquatic microorganisms (phytoplankton, zooplankton and benthos), as well as sedimented matter. At the end of the 4th instar, they accumulate nutritional reserves and become pupae. At this stage, insects do not feed and undergo the necessary changes that will make them reach adulthood, in which the transition from aquatic to terrestrial habitat occurs (Marcondes, 2011).

Adults are invertebrate metazoans, with bilateral symmetry, chitinous exoskeleton, segmented body and appendages articulated in pairs (Viveiros, 2010). According to Araújo (2011), it presents a dark coloring, white spots on the body and a lyre-shaped design present on its back, a characteristic that facilitates its identification with the naked eye.

The female of $A$. aegypti feeds on blood so that the maturation of the eggs can occur, and the hematophagy usually occurs during the day. Due to the need for blood meal, the female can disperse up to $800 \mathrm{~m}$ in search of food, being able to ingest from 3.0 to $3.5 \mathrm{mg}$ of blood in each food (Araújo, 2011).

In each oviposition, you can place around 50 to 200 eggs in water tanks. However, it is capable of performing numerous postures throughout its life, as it copulates only once with each male, and stores sperm in its spermatheque, where the sperm remains from insemination until before the fertilization of the eggs. When the eggs complete their ripening (gonadotrophic cycle), the female is able to lay. (Gadelha and Toda, 1985; Araújo, 2011).

The eggs of these culicids remain in a state of dormancy during the egg phase (quiescence), which allows it to have a pause in embryonic development, especially when environmental conditions are unfavorable (Azevedo, 2015).

Due to this resistance to variations in the environment and relatively short life cycle, the mosquito has spread rapidly. Infestations have become one of the main public health problems (Braga and Valle, 2007; Marchioro, 2016), given that this species is responsible for the transmission of diseases such as Dengue, Yellow Urban Fever (FAU), Chikungunya Fever and a Zika virus fever (Black et al., 2002; Luz et al., 2015). 
Dengue, known worldwide for affecting a large number of people, is transmitted by this culicid. The records of the first infestations of the dengue virus are dated to the end of the 13th century, in Java, an island in Southeast Asia and in Philadelphia, in the United States. However, only from the 20th century, the World Health Organization (WHO) started to recognize it as a disease (Ragonha and Nowak, 2018).

Dengue epidemics have occurred in Brazil since 1986 and have been caused by four serotypes of the DENV virus (DENV-1, 2, 3 and 4), belonging to the genus Falvivirus and family Flaviviridae (Braga and Valle, 2007; Marchioro, 2016). This disease has as main symptoms, an abrupt high fever, headache, pain behind the eyes, muscle and joint pain, skin rashes, which can cause death in cases of hemorrhagic dengue (Polanczyk et al., 2003).

Yellow fever is caused by an arbovirus of the genus Flavivirus, family Flaviviridae. The first outbreak recorded in Brazil occurred in the mid-eighteenth century, in the northeast region (Costa et al., 2018). According to the Brazilian Society of Infectious Diseases (SBI) the symptoms are classified as mild, moderate or severe, as follows:

a) Light form: The clinical picture is self-limited with fever and headache lasting two days. There is generally no direction for the diagnosis of yellow fever, except in epidemiological surveys, outbreaks and epidemics.

b) Moderate form: The patient has, for two to four days, signs and symptoms of fever, headache, myalgia and arthralgia, conjunctival congestion, nausea, asthenia and some hemorrhagic phenomena such as epistaxis. There may be subtlety. This form, like the mild form, evolves without complications or sequelae.

c) Serious form: In severe cases, after 5 to 6 days of incubation period, the onset of symptoms is abrupt and lasts for 4-5 days with high fever, accompanied by the Faget's sign (decreased pulse), severe headache, severe myalgia, jaundice, epistaxis, epigastric pain and hematemesis and melena (SBI, 2017, p. 6).

In addition to dengue and yellow fever, another arbovirus called Chikungunya, was recognized as an independent entity from dengue in 1950 (Morens and Fauci, 2014), and had its virus, called Chikungunya (CHIKV), Alphavirus of the Togaviridae Family, isolated primarily in Tanzania in 1952, due to an outbreak in the region (Aguirre, 2018).

It has a broad clinical aspect, with symptoms that appear four to seven days after infection, and may present in an acute or chronic form. As symptoms, individuals may experience high fever, chills, headache, vomiting, fatigue, back pain, muscle pain and symmetrical arthralgia, which can remain for a long time, considerably impairing the sick individual's quality of life (Castro et al., 2016).

Another febrile illness that is mainly transmitted by A. aegypti is fever by the Zika virus (ZIKV). This, in turn, is an RNA virus (ribonucleic acid virus), belonging to the genus Flavivirus, family Flaviviridae. It has three main strains, two from Africa, and one from Asia (Luz et al., 2015). Pinto Junior et al. (2015) points out that there is still no complete knowledge about the clinical manifestations caused by ZIKV. Despite this, the most abundant symptoms identified are, in addition to fever, headache, rash, edema, malaise and joint pain (Vasconcelos, 2015). Recent studies have also shown that Guillain-Barré Syndrome can also be related to previous Zika virus infection (Nóbrega et al., 2018).

\section{Aedes aegypti control strategies}

In 1955, the Brazilian government eradicated A. aegypti for the first time in history by planning practical actions against the yellow fever vector, with the support of the Pan American Health Organization and the World Health Organization. due to failures in entomological surveillance and intense urban growth, new infestations have been occurring (Braga and Valle, 2007; Marchioro, 2016). In this way, the development of 
preventive measures aimed at reducing the spread of mosquitoes, as well as effective control strategies, have been carried out constantly (Ragonha and Nowak, 2018).

Among the main methods for the control of $A$. aegypti, the mechanical, chemical and biological methods stand out. Mechanical control consists of eliminating mosquito breeding sites, properly managing materials, removing possible oviposition sites and imposing mechanical barriers so that the insect does not complete its life cycle (General Coordination of Health Surveillance, 2011).

Chemical control, as the name suggests, consists of the use of insecticides to control the adult form of the vector, which can only be used when there are confirmed cases (General Coordination of Health Surveillance, 2011). Among the nine products recommended by the WHOPES (Word Health Organization Pesticide Evaluation Scheme) for the chemical control of $A$. aegypti, five are neurotoxic, with four organophosphates and one spinosyn (Valle et al., 2015), as shown in Table 1.

Table 1. Products against larvae.

\begin{tabular}{|l|l|l|}
\hline Active principle & Action & Class \\
\hline Clorpirifos & Neurotoxic & organophosphate \\
\hline Fention & Neurotoxic & organophosphate \\
\hline Pirimifós-metil & Neurotoxic & organophosphate \\
\hline Temephos & Neurotoxic & organophosphate \\
\hline Spinosad & Neurotoxic & spinosyn \\
\hline Bacillus thuringiensis israelensis & Lysis of intestinal ephitelium & biolarvicide \\
\hline Diflubenzuron & development regulator & Chitin synthesis inhibitor \\
\hline Novaluron & development regulator & Chitin synthesis inhibitor \\
\hline Piriproxifen & development regulator & Juvenile hormone analog \\
\hline
\end{tabular}

Source: Valle et al. (2015).

Although chemical control is considered an effective method, it has been the subject of discussions due to its disadvantages, including environmental imbalance, selection of resistant insects and damage to human health (Lopes et al., 2017). In this sense, biological control has stood out in management programs, as it uses predators or pathogens, to reduce the vector population (Zara et al., 2016).

Among the various larvicides used as A. aegypti controllers, those of fungicidal origin (Gomes et al., 2015), plant extracts (Porto et al., 2017), seaweed (Salvador-Neto et al., 2016), essential oils (Ferreira et al., 2015), and different species of bacteria, as they have a great capacity for multiplication and dispersion in the environment (Pontes, 2018).

In this context, Bacillus thuringiensis (Bt) stands out, which, for producing highly toxic proteins for the larvae of this mosquito, has become one of the most important entomopathogenic species from a scientific, industrial point of view (Costa, 2009), and a commercial product most widespread in the national and international market for use in biological control (Blas-Cerdán et al., 2017).

\section{The discovery of Bacillus thuringiensis}

According to Nascimento (2003), Bt entomopathogenic bacteria were discovered and exploited commercially since the 20th century. In 1902 in Japan, Shigetane Ishiwata first described a spore-producing bacterium, responsible for the mortality of Bombyx mori 
(silkworm), calling it Bacillus sotto, this being the first mention of insect diseases caused by this type of bacteria (Silveira, 2008).

In 1911, Berliner redescribed the same bacterium isolated from caterpillars of the Anagasta kuhniella flour moth (Lepidoptera: Pyralidae), and, in 1915, started to call it Bacillus thuringiensis in honor of the region of Thuringia, Germany, where the caterpillars were collected (Whiteley and Schinepf, 1986; Dias, 1992; Glare and O'Callagham, 2000).

Berliner mentioned, in 1915, the presence of crystals in Bt spores, however, their activity was only discovered later (Polanczyk and Alves, 2003). From 1920, French farmers began to use Bt as a pesticide (UCSD, 2008). Ramos (2008) points out that the first insecticidal product used for agriculture, formulated and marketed from Bt spores, was developed in France from 1938. It was called Sporeine and used to control Plodia interpunctella (Lepidoptera: Pyralidae), popularly known as caterpillars of the flour moth.

In 1953, Hannay verified that the pathogenicity of Bt was determined by the protein inclusions formed during sporulation, a hypothesis validated by Angus in 1968 (Burges, 2001).

With the development of flagellar serology in 1962, there was a great advance in the systematics and classification of entomopathogenic bacilli for the subspecies Bacillus thuringiensis (Barjac and Franchon, 1990). This method of classification emerged as a solution to the great problems faced by scientists, due to the large number of varieties of bacilli that arose over time. It consists of testing the strain, hitherto unknown, in the presence of the antibodies of each bacterial lineage already known, allowing the specific differentiation of each one, based on cultural and biochemical characteristics (Medeiros, 2004).

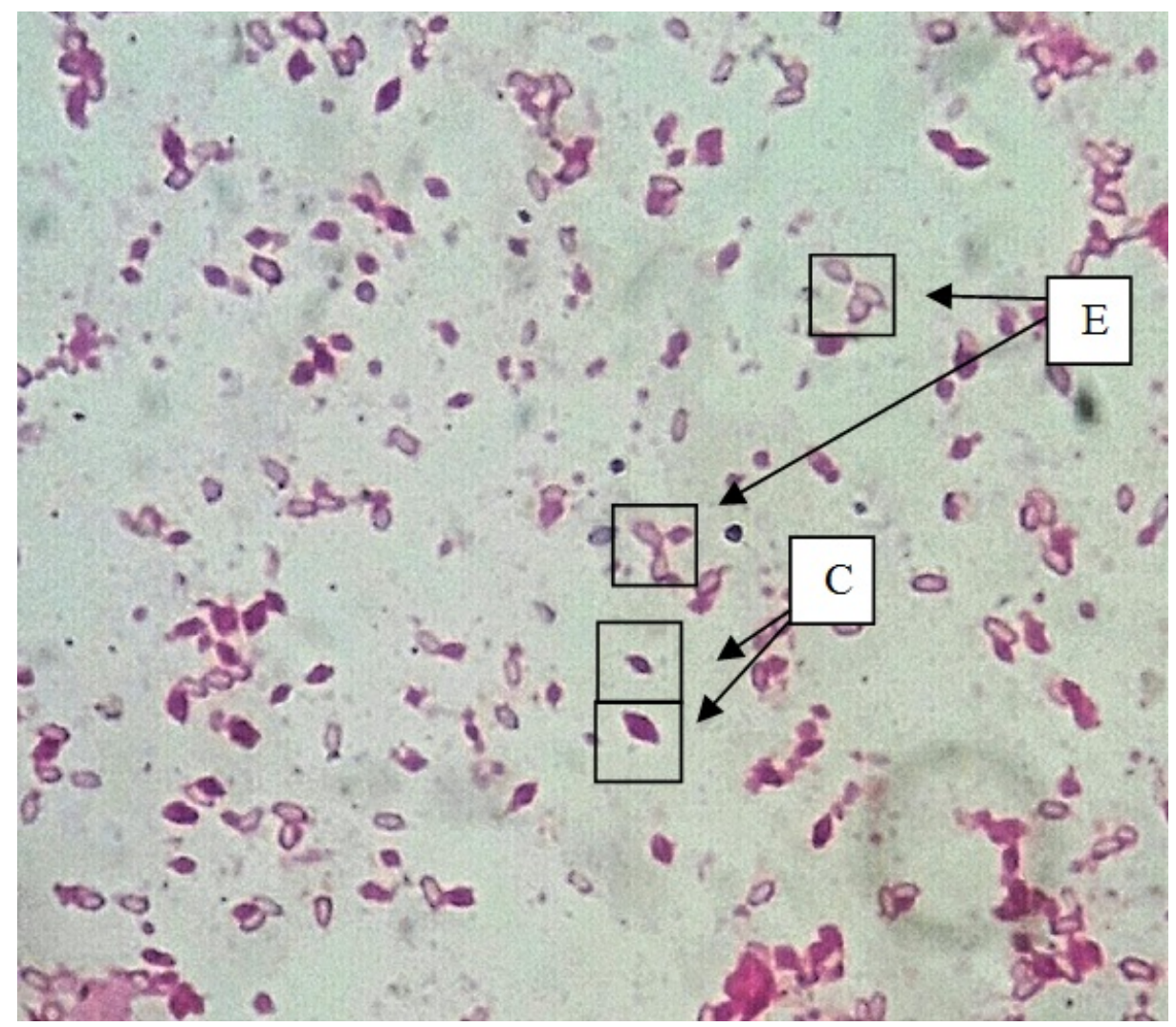

Figura 2. Photomicrograph of Bacillus spp. C - bipiramidal crystal; E - spore. Fuchsin staining. 1.000x magnification. Observed with immersion oil. 


\section{Bacillus thuringiensis}

Bacillus thuringiensis Berliner (Bt) are bacteria belonging to the Bracillacea family. Due to the shared genetic similarities, Bt is included in a complex with other species of bacilli, B. cereus, B. anthracis, B. mycoids, B. pseudomycoids, B. cytoxicius and B. weihenstephanensis (Sanahuja et al., 2011; Rabinovitch and Vivoni, 2016).

Like other bacteria, it can remain latent in the form of endospores under adverse conditions (Bobrowski et al., 2003). There are many strains of $\mathrm{Bt}$, and, during the sporulation phase, each of them produces one or more toxins concentrated in the form of protein crystals (Figure 2) (Galzer and Azevedo Filho, 2016; Garcia and Santos, 2016; Marchioro, 2016).

Due to its ecology, Bt is one of the most promising bacteria in biological control, with products based on this bacterium corresponding to approximately $90 \%$ of the world market for bioinsecticides (Vilas-Bôas et al., 2007), with about 50,000 strains known (Silveira, 2008).

It has the shape of a gram-positive rod, aerobically or optionally anaerobic, with a vegetative cell of 1.0 to $1.2 \mu \mathrm{m}$ wide by 3.0 to $5.0 \mu \mathrm{m}$ long, being found naturally in soils, forming spores. In addition to the soil, Bt isolation programs have found strains of this microorganism in living or dead insects, stored grains, phylloplane of plant species, as well as in water samples from rivers and lakes (Capalbo et al., 2005).

These toxins have shown entomopathogenic activity against insects of the orders Lepidoptera, Coleoptera, Hymenoptera and Diptera, in addition to nematodes, mites and protozoa (Schnepf et al., 1998; Praça et al., 2004). For this reason, it has been evaluated for the biological control of A. aegypti larvae, due to the advantages provided by the indiscriminate use of chemical insecticides over the years (Polanczyk et al., 2003).

\section{Bacillus thuringiensis toxins}

Bacillus thuringiensis produces, during sporulation in the mother cell, a parasporal crystal containing toxic proteins. These are active for several orders of insects and highly specific to their targets, however, they are harmless to humans, vertebrates and plants, in addition to being completely biodegradable (Pinto and Fiuza, 2008).

El-Bendary (2006) quotes that Rowe et al. (1987) and WHO (1999) describe nine toxins present in Bt lines, as shown in Table 1.

Table 1. Toxins described in Bacillus thuringiensis strains.

\begin{tabular}{|l|l|}
\hline Toxin & Comment \\
\hline$\alpha$-exotoxin & Phosphotypase C \\
\hline$\beta$-exotocin & Thermostable exotoxin \\
\hline$\gamma$-exotoxin & Toxic to insects of the suborder Symphyta (saw flies) \\
\hline$\delta$-endotoxin & Parasporal Crystal Protein \\
\hline Lice factor exotoxin & Active only against lice \\
\hline Rat factor exotoxin & Toxic against mice and Lepidoptera \\
\hline Vip3A & Vegetative insecticidal protein Bt \\
\hline Enterotoxin & Produced by vegetative cells \\
\hline
\end{tabular}

Source: Adapted from El-Bendary (2006).

Most Bt crystals are made up of Cry proteins, and they are encoded by genes usually located on plasmids, and, less frequently, on the bacterial chromosome (Galzer and 
Azevedo Filho, 2016). Currently more than 800 cry genes are described and, constantly, new genes are discovered.

In addition to Cry proteins, several other toxins can be produced by Bt, such as, Cyt protein, $\alpha$-exotoxin, $\beta$-exotoxin, hemolysins, enterotoxins, chitinases, proteases, phospholipases and vegetative insecticidal proteins (VIPs) (Lima, 2010; Corrêa, 2007; Galzer and Azevedo Filho, 2016).

The Cyt protein is produced mainly by the Israeli variety of Bt. It is a non-specific cytolysin, which accumulates in the crystals together with the $\delta$-endotoxins typical of this variety. It has a molecular weight of $28 \mathrm{kDa}$ (Costa et al., 2010).

A-exotoxin, also known as phospholipase C, is an enzyme with cytolytic activity, which acts on cell membrane phospholipids. It is highly toxic to some insects, either by oral or intrahemoceleic administration (Hansen and Salamitou, 2000).

B-exotocin (thuringiensin) is thermostable, acting by inhibiting nucleases, inhibiting RNA synthesis in cells and can cause lesions in tissues of mice and chickens, causing mutations in mammalian physiological systems, making their use controlled or even prohibited in some countries (Horta et al., 2017).

Chitinases and proteases are in the group of exoenzymes produced by Bt that play an important role in pathogenicity to insects (Lima, 2010). When released by the bacteria, they rupture the peritrophic membrane in the midgut, favoring the access of $\delta$-endotoxins to the epithelium (Reddy et al., 1998; Sampson and Gooday, 1998).

Vegetative insecticidal proteins (VIPs) represent one of the greatest discoveries regarding toxins with insecticidal capacity (Fang et al., 2007). Unlike Cry proteins, which unite in insoluble crystals within the mother cell, VIPs are secreted as soluble proteins by some Bt strains in their vegetative growth phase, which limits their application only in the field (Arora et al., 2003). They are produced in the initial stages of the growth of bacteria in culture, and therefore, as they are obtained in advance, both the supernatant and the mixture of spores and crystals obtained after the cultivation of Bt can be used (Monnerat and Bravo, 2000; Soberón and Bravo, 2001).

\section{Control of A. aegypti by Bacillus thuringiensis}

Few species of Bt have priority in synthesizing active protoxins against insects. Among them, B. thuringiensis subsp. israelensis (Bti) that acts only on the larvae (Nascimento, 2003). Several studies have demonstrated the efficiency of this bacterium in controlling the larvae of A. aegypti. Silva (2017) tested 553 strains of Bt in his work, of which 37 showed pathogenicity against the larvae. Of these strains, 12 caused $100 \%$ larval mortality within 24 hours, and 25 reached $100 \%$ death within 48 hours.

Dias (2016), identified 31 strains of $B$. thuringiensis subsp. israelensis, all of which showed toxicity to third instar larvae of $A$. aegypti. Katak (2015) also obtained positive results regarding the isolation of Bacillus spp. against $A$. aegypti larvae. Of the 41 strains tested, 10 showed larvicidal activity above $50 \%$. In the first 24 hours, only one strain had a mortality rate greater than $50 \%$. And after 48 hours, seven strains had a mortality rate greater than $50 \%$.

Lobo et al. (2018), also performed larvicide tests and obtained relevant results. In this study, $300 \mathrm{Bt}$ isolates were tested and 12 of them caused mortality in A aegypti larvae. Three of the 12 isolates caused $100 \%$ mortality within 24 hours. After 48 hours, four isolates caused a mortality rate of $90 \%$, two provided more than $80 \%$ mortality, two caused $76.6 \%$ mortality and one reached a mortality rate of $66.6 \%$.

\section{Mode of action of Bacillus thuringiensis toxins}

The specificity of Bti for culicid larvae is related to the presence of toxins that form in the bacteria during the sporulation phase. When these are ingested by the larvae, in alkaline conditions in the intestine, they are broken by the action of proteases, releasing 
toxic fractions. These bind to specific receptors on the epithelial membrane (Gill, 1995; Yousten, 1996).

According to Beltrão (2006), it is necessary that a series of events happen for the toxic activity of Bt to occur, as indicated in figure 3. Knowles and Ellar (1987); Aronson and Shai (2001) clarify that after ingestion, the proteins that are insoluble and attached to each other forming a crystal, are solubilized at an alkaline pH close to 10 of the mesenteric of most target insects, the first stage of Bti selectivity.

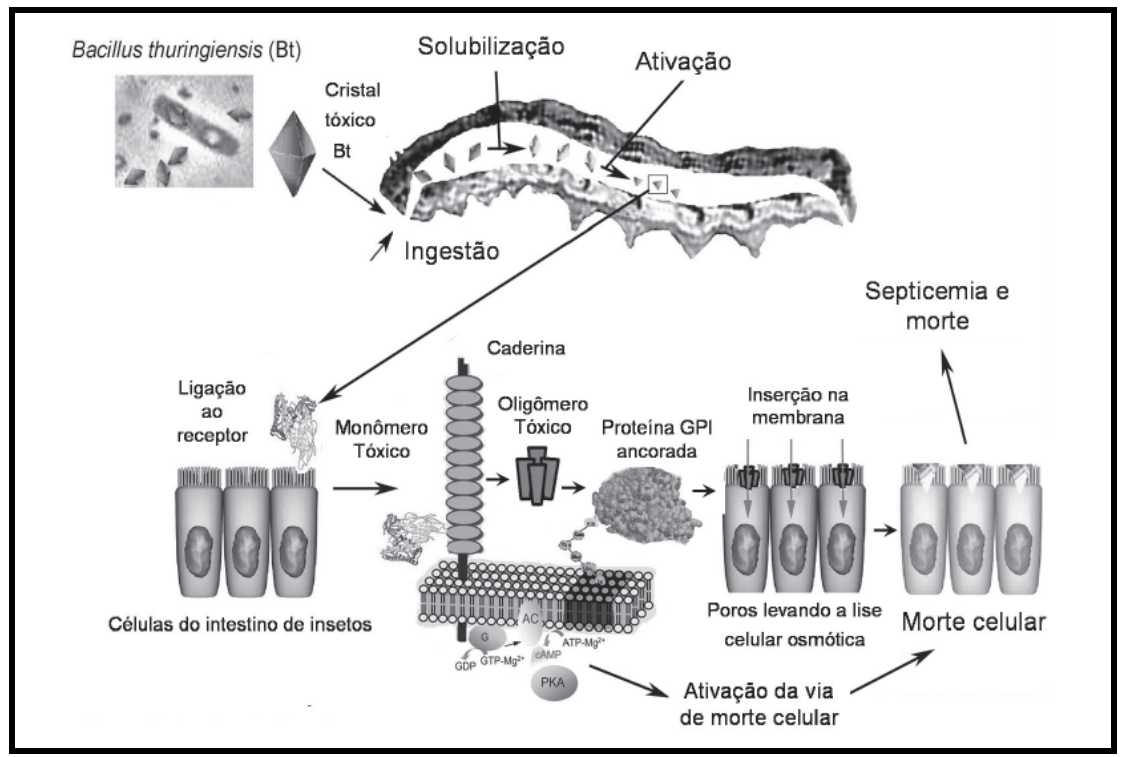

Figure 3. Mode of action of Bacillus thuringiensis in insects. Source: Adapted from Horta et al. (2017).

Later, protoxins are released in the larvae intestine, being converted into toxic polypeptides due to the proteolytic action of digestive enzymes. These toxins already activated cross the peritrophic membrane, binding to specific receptors of the apical membrane of columnar cells of the midgut, interfering in the ion gradient and osmotic balance of the apical membrane, increasing its permeability through the formation of pores. The consequence of these events is cell lysis, characterized by the disruption and disintegration of cells (Beltrão, 2006).

Recently, a second model of Bt action has been proven. In this case, protoxin, which was previously believed to be inactive and dependent on cleavage to act, may actually be more potent against resistant insects than its activated toxic fraction (Tabashnik et al., 2015).

This second model points out that there is no need to convert the protoxin into an activated toxin in order for it to be toxic, given that the target receptors are able to bind to the protoxin (Fabrick and Tabashnik, 2007). However, as this is a recent study, much remains to be said about the method, as well as its advantages and disadvantages regarding the classic model of action of Bt toxins.

In vitro experiments with Pectinophora gossypiella showed results that indicated that both the protoxin and the activated Cry1Ac toxin bound to fragments of cadherin, which consists of a key protein of the insect's medium intestine receptor (Fabrick and Tabashnik, 2007). 
Gómez et al. (2014) cites another in vitro experiment, carried out with Manduca sexta, which demonstrated that both the protoxin and the activated Cry1Ab toxin bound to the same cadherin fragment, so that the protoxin showed a slightly lower binding affinity with respect to activated toxin.

\section{Bacillus thuringiensis in the current market}

Although Bt has been used since 1960, only in 1977 after the discovery of Bacillus thuringiensis serovariety israelensis (Bti), this entomopathogen started to be used as a larvicide for diptera (Beltrão, 2006) being effective for species of the families Culicidae and Simuliidae (Delécluse et al., 2000).

As Monnerat points out; Bravo (2000), several laboratories around the world constantly seek to obtain new Bt isolates that produce new toxins or that are more adapted to local conditions, so that they can be used more efficiently, due to insect resistance. Currently, they represent 80 to $90 \%$ of the market for biological agents for mosquito control worldwide (Ootani et al., 2011).

Several Bti-based products are currently being marketed worldwide, as described in Table 2.

Table 2. Products based on Bacillus thuringiensis svar. israelensis available on the international market for use in culicidae and simulidae control programs.

\begin{tabular}{|c|c|c|}
\hline Commercial name & Formulation & Manufacturer \\
\hline Aquabac $\AA$ & Primary powder & Beckar Microbial/USA \\
\hline Bactimos WP® & Wettable powder & Valent BioSciences/USA \\
\hline Bactimos PP® & Primary powder & Valent BioSciences/USA \\
\hline Bactimos G® & Granules & Valent BioSciences/USA \\
\hline Ice Cubes $\AA$ & Ice granules & Icybac GMBH/Phoenix/Alemanha \\
\hline Teknar Hp-D® & Fluid concentrate & Thermo Trilogy/USA \\
\hline Teknar TC@ & Technical powder & Thermo Trilogy/USA \\
\hline Teknar G® & Granules & Thermo Trilogy/USA \\
\hline VectoBac $12 \mathrm{AS} \circledast$ & Fluid concentrate & Valent BioSciences/USA \\
\hline VectoBac TP® & Technical powder & Valent BioSciences/USA \\
\hline VectoBac WDG® & Water-dispersible granules & Valent BioSciences/USA \\
\hline VectoBac DT $囚$ & Tablets & Valent BioSciences/USA \\
\hline Bactecide $\AA$ & Water-dispersible granules & BioTech International Ltd/India \\
\hline Culinex Tab plus® & Tablets & Valent BioSciences/USA \\
\hline BioTouch $®$ & Fluid concentrate & Zohar Dalia/ Israel \\
\hline
\end{tabular}

Source: Beltrão (2006)

In Brazil, Bti-based products have acquired special importance, as this biolarvicide has been integrated to combat the vector of dengue (A. aegypti Control Program - PCA), conducted in hundreds of municipalities affected by the disease. Several breeding sites of A. aegypti received treatment based on this microorganism (Beltrão, 2006).

The use of these bacteria for the biological control of mosquito larvae, has stood out among the various strategies of pest management programs, having various formulations and being used against several species of mosquitoes. These products, generally have a price slightly higher than the products used, however, they are competitive when considering the social and environmental impacts of non-selective insecticides in aquatic systems (Vilarinhos et al., 1998; Polanczyk et al., 2003). 


\section{Final considerations}

Bacillus thuringiensis represents an efficient alternative for the control of Aedes aegypti. The advantages of using bacteria as a source of control are significantly considerable with regard to efficiency, environmental impacts and ease of production and commercialization.

It is necessary, however, that together with new control technologies, efficient forms of awareness are developed for the population, since the vector A. aegypti grows easily in the most varied places, in addition to being highly resistant to environmental characteristics. Only a joint action by science and conscience can eliminate this public health problem in Brazil and worldwide.

\section{Conflict of interest}

The authors declare that they have no conflicts of interest.

\section{References}

Aguirre, M. G. V. Manifestaciones artitogénicas y enfermedad por vírus chikungunya tras dos anos de la epidemia em Esmeralds. Emeralds: PUC, 2018 (Master dissertation).

Araújo, H. R. C. Caracterização morfológica dos hemócitos do Aedes aegypti e do Aedes albopictus e a resposta imune dos hemócitos do Aedes aegypti após a infecção pelo dengue vírus. Belo Horizonte: Fundação Oswaldo Cruz, 2011. (Doctorate thesis).

Aronson, A. I.; Shai, Y. Why Bacillus thuringiensis insecticidal toxins are so effective: Unique features of their mode of action. FEMS Microbiology Letters, v. 195, no. 1, p. 1-8, 2001. https://doi.org/10.1111/j.1574-6968.2001.tb10489.x

Arora, N.; Selvapandivan, U.; Agrawal, N. Bhhatnagar, R. Relocating expression of vegetative insecticidal protein into mother cell of Bacillus thuringiensis. Biochemical Biophysical Research Communications, v. 310, no. 1, p.158-162, 2003. https://doi.org/10.1016/j.bbrc.2003.08.137

Azevedo, J. B. Análise do ciclo do Aedes aegypti (Diptera: Culicidae) exposto a cenários de mudanças climáticas previstas pelo IPCC. Manaus: INPA, 2015. (Master dissertation).

Barjac, H.; Frachon, E. Classification of Bacillus thuringiensis strains. Entomaphaga, v. 35, no. 2, p. 233-240, 1990. https://doi.org/10.1007/BF02374798

Barros, V. R. M. Estudo de fatores de patogenicidade de Bacillus spp isolado em leite UHT. São Paulo: USP, 2004. (Doctorate thesis).

Becker, N. Bacterial control of vector-mosquitoes and black flies. In: Charles, J. F.; Delécluse, A.; LeRoux, C. N. Entomopathogenic bacteria: From laboratory to field application. Dordrecht: Kluwer Academic, 2000. p. 383-398.

Beltrão, H. B. M. Interação das toxinas Cry do Bacillus thuringiensis var. israelensis com o mesêntero de larvas do vetor Aedes aegypyi (Diptera: Culicidae). Recife: FIOCRUZ, 2006. (Master dissertation). 
Beserra. E. B.; Freitas, E. M.; Souza, J. T.; Fernandes, C. R. M.; Santos, K. D. Ciclo de vida de Aedes (Stegomyia) aegypti (Diptera, Culicidae) em águas com diferentes características. Iheringa, Série Zoologia, v. 99, no. 3, p. 281-285, 2009. https://doi.org/10.1590/S007347212009000300008

Black IV, W. C.; Bennett, K. E.; Gorrochótegui-Escalante, N.; Barillas-Mury, C. V.; FernándezSalas, I.; Muñoz, M. L.; Farfán-Alé, J. A.; Olson, K. E.; Beaty, B. J. Flavivirus susceptibility in Aedes aegypti. Archives of Medical Research, v.33, no. 4, p.379-388, 2002. https://doi.org/10.1016/s0188-4409(02)00373-9

Blas-Cerdán, W.; Zavaleta-Espejo, G.; Saldaña-Jiménez, J.; Blas-Roeder, W.; MeléndezRodriguez, D. Efecto biocida de Bacillus thuringiensis H-14 var. israelensis mutante sobre larvas III de Aedes aegypti bajo condiciones de laboratorio. Revista Científica de la Faculdad de Ciencias Biológicas, v. 37, no. 2, p. 14-21, 2017.

Bobrowski, V. L.; Fiuza, L. M.; Pasquali, G. P.; Bonadese-Zanettini, M. H. Genes de Bacillus thuringiensis: uma estratégia para conferir resistência a insetos em plantas. Ciência Rural, v. 34 , no. $1, \quad$ p. 843-850, 2003. https://doi.org/10.1590/S010384782003000500008

Braga, I. A.; Valle, D. Aedes aegypti: inseticidas, mecanismos de ação e resistência. Epidemiologia e Serviços de Saúde, v. 16, p. 279-293, 2007. https://doi.org/10.5123/ S1679-49742007000400006

Burges, H. D. Bacillus thuringiensis in pest control. Horticulture Research International, v. 3, p. 90-98, 2001. https://doi.org/10.1039/b104591c

Capalbo, D. M. F.; Vilas-Bôas, G. T.; Arantes, O. M. N.; Suzuki, M. T. Bacillus thuringiensis. Biotecnologia, Ciência \& Desenvolvimento, no. 34, p. 78-85, 2005.

Castro, A. P. C. R.; Lima, R. A.; Nascimento, J. S. Chikungunya: Vision of the pain clinician. Revista Dor, v. 17, no. 4, p. 299-302, 2016. https://doi.org/10.5935/18060013.20160093

Chui, V. W. D.; Wong, K. W.; Tsoi, K. W. Control of mosquito larvar (Diptera: Culicidae) using Bti and teflubenzuron: Laboratory evaluation and semi-field test. Environment International, $\quad$ v. 21 , no. 4 , p. $433-440, \quad 1995 . \quad$ https://doi.org/10.1016/01604120(95)00037-L

Consoli, R. A. G. B.; Lourenço-de-Oliveira, R. Principais mosquitos de importância sanitária no Brasil. Rio de Janeiro: FIOCRUZ, 1994.

Coordenadoria Geral de Vigilância em Saúde. Controle vetorial. Porto Alegre: Programa Municipal de Prevenção à Dengue, 2011.

Corrêa, R. F. T. Estudo da atividade tóxica para Aedes aegypti das proteínas Cry4Aa e Cry4Ba de Bacillus thuringiensis expressas em baculovírus recombinantes. Brasília: UNB, 2007. (Thesis master degree).

Costa, J. R. V. Predição in vitro da atividade tóxica de isolados de Bacillus thuringiensis Berliner e efeito sinergístico no controle de larvas de Aedes aegypti (L.) (Diptera: Culicidae). Jaboticabal: Paulista State University "Julio de Mesquita Filho", 2009. (Doctorate thesis).

Costa, J. R. V.; Rossi, J. R.; Marucci, S. C.; Alves, E. C.; Vope, H. X. L.; Ferraudo, A. S.; Lemos, M. V. F.; Desidério, J. A. Atividade tóxica de isolados de Bacillus thuringiensis a larvas de Aedes aegypti (L.) (Diptera: Culicidade). Neotropical Entomology, v. 39, no. 5, p. 757-766, 2010. https://doi.org/10.1590/S1519-566X2010000500015 
Costa, R. M.; Facioli, L. S.; Reis, T. D. F.; Dá, O. R.; Bernardes, N. B. Febre amarela: sua perspectiva no Brasil. Id on Line - Revista Multidisciplinar e de Psicologia, v. 12, no. 41, p. 435-448, 2018. https://doi.org/10.14295/idonline.v12i41.1209

Delécluse, A.; Pérez, V. J.; Berry, C. Vector-active toxins: Structure and diversity. In: Charles, J.-F.; Delécluse, A.; Nielsen-Leroux, C. (Eds.). Entomopatogenic bacteria: From laboratory to field application. Dordrecht: Kluwer Academic Press, 2000. p. 101-122.

Dias, J.M.C.S. Produção e utilização de bioinseticidas bacterianos. Pesquisa Agropecuária Brasileira, v. 27, p. 59-76, 1992.

Dias, M. L. Bioprospecção de estirpes de Bacillus thuringiensis subsp. israelensis para Aedes aegypti e Culex quinquefasciatus (Diptera: Culicidae). Gurupi: UFT, 2016. (Thesis master degree).

El-Bendary, M. A. Bacillus thuringiensis sphaericus biopesticides production. Journal of Basic Microbiology, v. 46, no. 2, p. 158-170, 2006. https://doi.org/10.1002/ jobm.200510585

Fabrick, J. A.; Tabashnik, B. E. Binding of Bacillus thuringiensis toxin Cry1Ac to multiple sites of cadherin in pink bollworm. Insect Biochemistry and Molecular Biology, v. 37, p. 97-106, 2007. https://doi.org/10.1016/j.ibmb.2006.10.010

Fang, J.; Xu, X.; Wang, P.; Zhao, J-Z.; Shelton, A. M.; Cheng, J.; Feng, M-G.; Shen, Z. Characterization of chimeric Bacillus thuringiensis Vip3 toxins. Applied and Environmental Microbiology, v. 73, no.3, p. 956-961, 2007. https://doi.org/10.1128/ aem.02079-06

Ferreira, S. G.; Conceição, V. S.; Gouveia, N. S.; Santos, G. S.; Santos, R. L. C.; Lira, A. A. M.; Calvacanti, S. C. H.; Sarmento, V. H. V.; Nunes, R. S. An environmentally safe larvicidae against Aedes aegypti based on in situ gelling nanostructured surfactante systems containing an essential oil. Journal of Colloid and Interface Science, v. 456, p. 190-196, 2015. https://doi.org/10.1016/j.jcis.2015.06.012

Gadelha, D. P.; Toda, A. T. Biologia e comportamento do Aedes aegypti. Revista Brasileira de Malariologia e Doenças Tropicais, no. 37, p. 29-36, 1985.

Galzer, E. C. W.; Azevedo Filho, W. S. Utilização do Bacillus thuringiensis no controle biológico de pragas. Revista Interdisciplinar de Ciência Aplicada, v. 1, no. 1, p. 1-4, 2016.

Garcia, A. C. H.; Santos, V. I. M. Seleção de ativos biológicos de Bacillus thuringiensis com potencial de inibição de microrganismos. Brasília: UNICEUB, 2016. (Cientific Initiation Program).

Gill, S. Mechanism of action of Bacillus thuringiensis toxins. Memórias do Instituto Oswaldo Cruz, v. 90, p. 69-74, 1995.

Glare, T. R.; O'Callaghan, M. Bacillus thuringiensis: Biology, ecology and safety. Chichester: John Wiley, 2000.

Gomes, S. A.; Paula, A. R.; Ribeiro, A.; Moraes, C. O. P.; Santos, J. W. A. B.; Silva, C. P.; Samuels, R. I. Neem oil increases the efficiency of the entomopathogenic fungus Metarhizium anisopliae for the control of Aedes aegypti (Diptera: Culicidae) larvae. Parasites \& Vectors, v. 8, no. 669, p. 2-8, 2015. https://doi.org/10.1186/s13071-015$1280-9$ 
Gómez, I.; Sánchez, J.; Muñoz-Garay, C.; Matus, V.; Gill, S. S.; Soberón, M.; Bravo, A. Bacillus thuringiensis Cry1A toxins are versatile proteins with multiple modes of action: Two distinct pre-pores are involved in toxicity. Biochemistry Journal, v. 459, p. 383-396, 2014. https://doi.org/10.1042/bj20131408

Hansen, B. M.; Salamitou, S. Virulence of Bacillus thuringiensis. In: Charles, J. F.; Delecluse, A.; Nielsen-Le Roux, C. (Eds). Entomopathogenic bacteria: From laboratory to field application. Kluwer Academic Publishers: Netherland, 2000. p. 41-44.

Horta, A. B.; Pannuti, L. E. R.; Baldin, E. L. L.; Furtado, E. L. Toxinas inseticidas de Bacillus thuringiensis. In: Resende, R. R. Biotecnologia aplicada à Agro\&Indústria. 1. ed. São Paulo: Blücher, 2017. p. 737-774.

Katak, R. M. Seleção de Bacillus spp. da Amazônia brasileira portadores de genes Cry e/ou PhaC via síntese de polihidroxiacalnoatos (PHAs) para o controle de Aedes aegypti Linnaeus 1762. Manaus: UFAN, 2015. (Thesis master degree).

Knowles, B. H.; Ellar, D. J. Colloid-osmotic lysis is a general feature of the mechanism of action of Bacillus thuringiensis $\delta$-endotoxins with diferente insect specificity. Biochimica et Biophysica Acta (BBA) - General Subjects, v. 924, p. 509-518, 1987. https://doi.org/ 10.1016/0304-4165(87)90167-X

Lima, G. M. S. Proteínas bioinseticidas produzidas por Bacillus thuringiensis. Proceedings of the Pernambuco Academy of Agricultural Science, v. 7, p. 119-137, 2010.

Lobo, K. S.; Soares-da-Silva, J.; Silva, M. C.; Tadei, W. P.; Polanczyk, R. A.; Pinheiro, V. C. S. Isolation and molecular characterization of Bacillus thuringiensis found in soils of the Cerrado Region of Brazil, and their toxicity to Aedes aegypti larvae. Revista Brasileira de Entomologia, 62, p. 5-12, 2018. https://doi.org/10.1016/j.rbe.2017.11.004

Lopes, T. S.; Campos Júnior, E. O.; Cocco, D. D. A. O uso do detergente como larvicida alternative no controle às larvas do Aedes aegypti. Getec, v. 6, no. 11, p. 167-176, 2017.

Lounibos, L. P. Invasion by insect vectors of human disease. Annual Review of Entomology, v. 47, p. 233-266, 2002. https://doi.org/10.1146/annurev.ento. 47.091201.145206

Lourenço-de-Oliveira, R.; Vazeille, M.; Filippis, A. M. B.; Failloux, A. B. Aedes aegypti in Brazil: Genetically differentiated populations with high susceptibility to dengue and yellow fever viruses. Transactions of The Royal Society of Tropical Medicine and Hygiene, v. 98, no. 1, p. 43-54, 2004. https://doi.org/10.1016/s0035-9203(03)00006-3

Luz, K. G.; Santos, G. I. V.; Vieira, R. M. Febre pelo vírus Zika. Epidemiologia e Serviços de Saúde, v. 24, no. 4, p. 785-788, 2015. https://doi.org/10.5123/S167949742015000400021

Marchioro, G. M. Isolamento de Bacillus thuringiensis de diferentes regiões de Sergipe e avaliação da toxicidade das estirpes sobre larvas de Aedes aegypti. São Cristóvão: UFSE, 2016. (Conclusion course paper graduation).

Marcondes, C. B. Entomologia médica e veterinária. 2. ed. São Paulo: Atheneu, 2011.

Medeiros, P. T. Estirpes brasileiras de Bacillus thuringiensis efetivas no controle biológico da traça-das-crucíferas Putella xylostella. Cuiabá: UFMG, 2004. (Thesis master degree). 
Miller, B. R.; Ballinger, M. E. Aedes albopictus mosquitos introduced into Brazil: Vector competence for yellow fever and dengue viruses. Transactions of The Royal Society of Tropical Medicine and Hygiene, v. 82, no. 3, p. 476-477, 1988. https://doi.org/10.1016/ 0035-9203(88)90168-x

Monnerat, R. G.; Bravo, A. Proteínas bioinseticidas produzidas pela bactéria Bacillus thuringiensis: modo de ação e resistência. In: Melo, I. S. (Ed.). Controle biológico. Jaguariúna: Embrapa Meio Ambiente, 2000. v. 3.

Morens, D. M.; Fauci, A. S. Chikungunya at the door: Déjà vu all over again? The New England Journal of Medicine, v. 371, p. 885-887, 2014. https://doi.org/10.1056/ NEJMp1408509

Nascimento, A. K. S. 0 uso do Bacillus thuringiensis variedade israelensis, no controle das larvas do Aedes aegypti. Brasília: UNICEUB, 2003. (Conclusion course paper graduation).

Neves, D. P. Parasitologia humana. 11. ed. São Paulo: Atheneu, 2005.

Nóbrega, M. E. B.; Araújo, E. L. L.; Wada, M. Y.; Leite, P. L.; Dimech, G. S.; Pércio, J. Surto de Síndrome de Guillain-Barré possivelmente relacionado à infecção prévia pelo vírus Zika, Região Metropolitana do Recife, Pernambuco, Brasil, 2015. Epidemiologia e Serviços de Saúde, v. 27, no. 2, p. 1-12, 2018. https://doi.org/10.5123/s1679-49742018000200016

Ootani, M. A.; Ramos, A. C. C.; Azevedo, E. B.; Garcia, B. O.; Santos, S. F.; Aguiar, R. W. S. Avaliação da toxicidade de estirpes de Bacillus thuringiensis para Aedes aegypti Linneus (Diptera: Culicidae). Journal of Biotechnology and Biodiversity, v. 2, no. 2, p. 37-47, 2011.

Pinto Junior, V. L.; Luz, K.; Parreira, R.; Ferrinho, P. Vírus Zika: revisão para clínicos. Acta Médica Portuguesa, v. 28, no. 6, p. 760-765, 2015.

Pinto, L. M. N.; Fiuza, L. M. Genes cry de Bacillus thuringiensis aplicados na Engenharia Genética de plantas, conferindo resistência a insetos-praga. Neotropical Biology and Conservation, v. 3, no. 3, p. 159-168, 2008. https://doi.org/10.4013/nbc.20083.07

Polanczyk, R. A.; Alves, S. Bacillus thuringiensis: uma breve revisão. Revista Brasileira de Agropecuária, v. 7, no. 2, p. 1-10, 2003.

Polanczyk, R. A.; Garcia, M. O.; Alves, S. B. Potencial de Bacillus thuringiensis israelensis Berliner no controle de Aedes aegypti. Revista Saúde Pública, v. 37, no. 6, p. 813-816, 2003. https://doi.org/10.1590/S0034-89102003000600020

Pontes, G. O. Seleção de fungos filamentosos de solos da Amazônia para controle biológico de larvas e adultos de Aedes aegypti L. vetor dos vírus da dengue, Chikungunya e Zika. Manaus: UFAM, 2018. (Thesis doctorate).

Porto, K. R. A.; Motti, P. R.; Yano, M.; Roel, A. R.; Cardoso, C. L. A.; Matias, R. Sreening of plant extracts and fractions on Aedes aegypti larvae found in the State of Mato Grosso do Sul (Linnaeus, 1762) (Culicidae). Anais da Academia Brasileira de Ciências, v. 89, no. 2, p. 895-906, 2017.

Praça, L. B.; Batista, A. C.; Martins, E. S.; Siqueira, C. B.; Dias, D. G. S.; Gomes, A. C. M.; Falcão, R.; Monnerat, R. G. Estirpes de Bacillus thuringiensis efetivas contra insetos das Ordens Lepidoptera, Coleoptera e Diptera. Pesquisa Agropecuária Brasileira, v. 39, p. 11-16, 2004.

Rabinovitch, L.; Vivone, A. M. Bacillus e Bacillus cereus com suas facetas como bactérias esporuladas gram-positivas. UPpharma, p. 8-10, 2016. 
Ragonha, F. H.; Nowak, R. G. A evolução e potencialização do Aedes aegypti em relação às doenças no Brasil e no Estado do Paraná. Arquivos do MUDI, v. 22, no. 1, p. 48-78, 2018. https://doi.org/10.4025/arqmudi.v22i1.41521

Ramos, F. R. Avaliação a campo de uma estiroe de Bacillus thuringiensis tóxica à Lepidoptera e seu possível efeito adverso sobre espécies não-alvo. Brasília: University of Brasília, 2008. (Master dissertation).

Reddy, S. T.; Kumar, N. S.; Venkateswerlu, G. Comparative analysis of intracellular proteases in sporulates Bacillus thuringiensis strains. Biotechnology Letter, v. 20, p. 279-281, 1998. https://doi.org/10.1023/A:1005338205018

Rowe, G. E.; Margaritis, A.; Dulmage, H. T. Bioprocess developments in the production of bioinsecticides by Bacillus thuringiensis. Critical Reviews in Biotechnology, v. 6, no. 1, p. 87-127, 1987. https://doi.org/10.3109/07388558709086986

Salvador-Neto, O.; Gomes, S. A. R.; Machado, F. L. S.; Samuels, R. I.; Fonseca, R. N.; SouzaMenezes, J.; Moraes, J. L. C.; Campos, E.; Mury, F. B.; Silva, J. R. Larvicidal potential of the halogenated sesquiterpense (+)-obtusol, isolated from the alga Laurencia dendroidea J. Agardh (Ceramiales: Rhodomelaceae), against the dengue vector mosquito Aedes aegypti (Linnaeus) (Diptera: Culicidae). Marine Drugs, v. 14, no. 20, p. 2-14, 2016.

Sampson, M. N.; Gooday, G. W. Involvemente of chitinases of Bacillus thuringiensis during pathogenesis in insects. Microbiology, v. 144, p. 2189-2194, 1998. https://doi.org/ 10.1099/00221287-144-8-2189

Sanahuja, G.; Banakar, R.; Twyman, R. M.; Capell, T.; Christou, P. Bacillus thuringiensis: A century of research, development and commercial applications. Plant Biotechnology Journal, v. 9, no. 3, p. 283-300, 2011. https://doi.org/10.1111/j.1467-7652.2011.00595.x

SBI - Sociedade Brasileira de Infectologia. Febre amarela: Informativo para profissionais de saúde. SBI, 2017.

Schnepf, E.; Crickmore, N.; Rie, J. V.; Lereclus, D.; Baum, J.; Feitelson, J.; Zeigler, D. R.; Dean, D. H. Bacillus thuringiensis and its pesticidal crystal proteins. Microbiology and Molecular Biology Review, v. 62, p. 775-806, 1998. https://doi.org/10.1128/ MMBR.62.3.775-806.1998

Silva, J. S. Seleção de isolados de Bacillus thuringiensis Berliner, 1911 ativos para larvas de Aedes aegypti Linnaeus, 1762, Anopheles darlingi Root, 1926 e Culex quinquefasciatus Say, 1823 (Diptera: Culicidae) e caracterização das toxinas mosquitocidas. Manaus: INPA, 2017. 145 p. (Thesis doctorate).

Silveira, L.F.V. Seleção de isolados de Bacillus thuringiensis Berliner para Tetranychus urticae Koch. Alegre: UFES, 2008. (Master dissertation).

Soberón, M.; Bravo, A. Bacillus thuringiensis y sus toxinas insecticidas. In: Martinez, E.; Martinez, J. C. (Eds.). Microbios en linea. Mexico: Universidad Nacional Autónoma de Mexico, 2001.

Tabashnik, B. E.; Zhang, M.; Fabrick, J A.; Wu, Y.; Gao, M.; Huang, F.; Wei, J.; Zhang, J.; Yelich, A.; Unnithan, G. C.; Bravo, A. Soberón, M.; Carrière, Y.; Li, X. Dual mode of action of Bt proteins: Protoxin efficacy against resistant insects. Scientific Reports, v. 5, 15107, 2015. https://doi.org/10.1038/srep15107

UCSD - University of California. Bacillus thuringiensis, history of Bt. San Diego: UCSD, 2008. 
Valle, D.; Pimenta, D. N.; Cunha, R. V. (Orgs.). Dengue: teorias e práticas. Rio de Janeiro: FIOCRUZ, 2015.

Vasconcelos, P. F. C. Doença pelo vírus Zika: um novo problema emergente nas Américas. Revista Pan-Amazônica de Saúde, v. 6, no. 2, p. 9-10, 2015. https://doi.org/10.5123/ S2176-62232015000200001

Vilarinhos, P. T. R.; Dias, J. M. C. S.; Andrade, C. F. S.; Araújo-Coutinho, C. J. P. C. Uso de bactérias para o controle de culicídeos e simulídeos. In: Alves, S. B. Controle microbiano de insetos. Piracicaba: Fundação de Estudos Agrários Luiz de Queiroz, 1998. p. 447-480.

Vilas-Bôas, G. T.; Peruca, A. P. S.; Arantes, O. M. N. Biology and taxonomy of Bacillus cereus, Bacillus anthracis and Bacillus thuringiensis. Canadian Journal of Microbiology, v. 53, no. 1, p. 673-687, 2007. https://doi.org/10.1139/w07-029

Viveiros, B. C. C. Estudo biológico do Aedes (Stegomya) aegypti Diptera: Culicidae no Arquipélago da Madeira. Lisbon: Institute of Hygiene and Tropical Medicine, Universidade Nova de Lisboa, 2010. (Master degree thesis).

Whiteley, H. R.; Schnepf, H. E. The molecular biology of parasporal crystal body formation in Bacillus thuringiensis. Anual Review of Microbiology, v. 40, p. 549-576, 1986. https://doi.org/10.1146/annurev.mi.40.100186.003001

WHO - World Health Organization. Microbial pest control agent Bacillus thuringiensis. Geneva: WHO, 1999. (Report of UNEP/ILO/WHO EHC, 217).

Yousten, A. A. Mosquitocidal toxins from bacteria of the genus Bacillus. Anais do V SINCOBIOL - Symposium on Biological Control, Foz do Iguaçu, p. 304-309, 1996.

Zara, A. L. S. A.; Santos, S. M.; Fernandes-Oliveira, E. S.; Carvalho, R. G.; Coelho, G. E. Estratégias de controle do Aedes aegypti: uma revisão. Epidemiologia e Serviços de

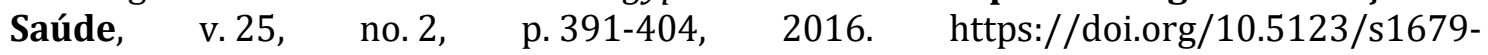
49742016000200017

Zettel, C.; Kaufman, P. Aedes aegypti. Florida: UF, 2008.

License information: This is an open-access article distributed under the terms of the Creative Commons Attribution License, which permits unrestricted use, distribution, and reproduction in any medium, provided the original work is properly cited. 